\title{
KEPEMIMPINAN PEREMPUAN DALAM PENDIDIKAN ISLAM
}

\section{(Studi atas Peran Umi Waheeda dalam Mengelola Yayasan} Al-Ashriyyah Nurul Iman Islamic Boarding School Parung)

\author{
Siti Kafidhoh \\ Sekolah Tinggi Agama Islam Nurul Iman Parung Bogor \\ Email: sitikafidhoh@stainuruliman.ac.id
}

\begin{abstract}
Women's Leadership in Islamic Education (Study on Role of Umi Waheeda in Managing Al-Ashriyyah Nurul Iman Islamic Boarding School Parung Bogor). This research found that the most dominant female leadership style shown by Umi Waheeda in managing Pesantren Nurul Iman is the Melati Style, with the main characteristic of simple, polite and wise leadership in all its members. This is also reinforced by the nature of leadership shown by Umi Waheeda with the nature of the mother and iron maden. Umi Waheeda shows maternal traits in directing employees, and has always been a strong and visionary women leader.Another interesting thing found in this study, in the perspective of Umi Waheeda employees, it shows the uniqueness of being a leader so that it becomes a characteristic of female leaders who distinguishes from other leaders including: 1) Umi Waheeda as a strong leader woman, 2) productive leader, by developing various social entrepreneurs; 3) Independent Free Education Initiators, in the sense that without relying on donations from other institutions; 4) The Trusty Leader, by establishing a non-profit institution to provide thousands of orphans and underprivileged people in terms of education, health, and free residence with istiqomah; 5) A progressive leader, provides periodic and continuous progress for the Al-Ashriyyah pesantren Nurul Iman.
\end{abstract}

Keywords: women's leadership, Islamic studies 


\begin{abstract}
ABSTRAK
Kepemimpinan Perempuan dalam Pendidikan Islam (Studi atas Peran Umi Waheeda dalam Mengelola Yayasan Al-Ashriyyah Nurul Iman Islamic Boarding School Parung Bogor). Hasil penelitian ini menemukan bahwasannya gaya kepemimpinan perempuan yang paling dominan ditunjukkan oleh Umi Waheeda dalam mengelola Pesantren Nurul Iman adalah Gaya Melati, dengan ciri utama sederhana, suri tauladan dan bijaksana dalam memimpin seluruh anggotanya. Hal ini dikuatkan juga dengan sifat kepemimpinan yang ditunjukkan oleh Umi Waheeda dengan sifat the mother dan iron maden. Umi Waheeda memperlihatkan sifat keibuan dalam mengarahkan karyawan, serta selalu menjadi perempuan pemimpin yang tangguh dan visioner. Hal menarik lain yang ditemukan dalam penelitian ini adalah, dalam perspektif karyawan Umi Waheeda memperlihatkan keunikan sebagai seorang pemimpin sehingga menjadi karakteristik pemimpin perempuan yang membedakan dengan pemimpin lainnya diantaranya: 1) Umi Waheeda sebagai perempuan pemimpin yang tangguh, 2) pemimpin yang produktif, dengan mengembangkan berbagai wirasusaha sosial; 3) Inisiator Pendidikan Gratis yang Mandiri, dalam artian tanpa bergantung pada donasi lembaga lain; 4) Pemimpin yang Penyantun, dengan mendirikan lembaga non-profit untuk memberi santunan ribuan yatim piatu dan masyarakat kurang mampu dalam segi pendidikan, kesehatan, dan tempat tinggal gratis dengan istiqomah; 5) Pemimpin yang progressif, memberikan kemajuan berkala dan terus menerus bagi pesantren Al-Ashriyyah Nurul Iman.
\end{abstract}

Kata Kunci: Kepemimpinan, Perempuan, Pendidikan Islam 


\section{Pendahuluan}

Wacana kepemimpinan perempuan ${ }^{1}$ di Indonesia telah mencuat ke permukaan sejak era tahun 1998. Diskursus wacana pemimpin perempuan telah memancing polemik pro-kontra dalam masyarakat yang secara umum bersifat patrilineal. Polemik tersebut berimplikasi pada sebuah wacana pada pengingkaran eksistensi perempuan sebagai manusia yang mandiri, dan lebih jauh tentang kelayakan perempuan menjadi pemimpin baik di ranah domestik ataupun publik. Tidak semua perempuan dapat diakui sebagai pemimpin, hanya perempuanperempuan yang memenuhi standar kepemimpinan laki-laki yang dapat diakui efektivitasnya dalam kepemimpinan.

Berdasarkan data dari Kementrian Pemberdayaan Perempuan dan Perlindungan Anak RI (2013), meskipun Indonesia, Laos, dan Kamboja telah melakukan berbagai macam program kesetaraan gender, tiga negara tersebut termasuk negara dengan indeks ketimpangan gender yang tinggi.

Keraguan masyarakat akan sosok pemimpin perempuan agaknya terlihat kontras dengan fakta sejarah Bangsa Indonesia. Nama-nama seperti Cut Nya Dien, Cut Meutiah, Ratu Saylendra, Ken Dedes, dan Raden Ajeng Kartini rasanya pantas disejajarkan dengan nama-nama pejuang pria di negeri ini.

Siapapun bisa menjadi pemimpin, karena pada intinya baik laki-laki maupun perempuan bisa mempunyai kriteria syaratsyarat sebagai pemimpin. Namun ternyata dalam pandangan tradisional, perempuan diidentikkan dengan sosok yang lemah, halus dan emosional. Sementara laki-laki digambarkan sebagai sosok yang gagah, berani, dan rasional. Pandangan ini telah memposisikan perempuan sebagai makhluk yang seolah-olah harus dilindungi dan senantiasa bergantung pada kaum laki-laki. Akibatnya, jarang sekali perempuan untuk bisa tampil menjadi pemimpin, karena mereka tersisihkan oleh dominasi laki-laki dengan male chauvinistic-nya. Dengan demikian maka muncul

${ }^{1}$ Para kaum feminis Indonesia lebih suka menggunakan kata perempuan daripada wanita. Dalam prasasti Gandasuli disebutkan bahwa asal kata perempuan adalah Parpuanta yang memiliki arti yang dipertuankan atau dihormati, Empu dalam pengertian ini merupakan sebuah gelar kehormatan yang berarti tuan. Namun menurut William Shakespeare (seorang pujangga Inggris) apapun namanya wanita atau perempuan sama saja, yaitu satu jenis makhluk manusia yang paling berjasa terhadap spesiesnya secara biologis yang memungkinkan manusia bisa lebih banyak dan silih berganti dari generasi ke generasi. Lihat Zaitunah Subhan, Kodrat Perempuan: Takdir atau Mitos (Yogyakarta: Pustaka Pesantren, 2004), Hal. 4-8. 
anggapan bahwa kaum laki-laki lebih pantas memimpin dari pada perempuan. Apalagi diperkuat lagi oleh kebanyakan teori-teori kepemimpinan yang tidak hanya menolak peran perempuan dalam lembaga pendidikan, tetapi juga mengalami bias gender dan terbentuk asumsi-asumsi yang tidak benar tentang peran gender dalam organisasi. Kebanyakan teori hanya memfokuskan pada peran laki-laki dalam organisasi. ${ }^{2}$ Bahkan, sebagian masyarakat beranggapan bahwa laki-laki lebih pantas menjadi pemimpin dalam setiap bidang kehidupan. Di antara yang menyebabkan pandangan itu bisa terjadi, antara lain disebabkan oleh:

Pertama, menurut teori yang ada menyebutkan bahwa pemimpin tidak harus laki-laki dan adanya anggapan yang pantas menjadi pemimpin adalah laki-laki merupakan isu gender serta adanya budaya patriarkhi yang melekat di Indonesia menyebabkan perempuan sering dianggap sebagai orang yang lemah karena selalu dinomerduakan.

Kedua, adanya penyimpangan dalam pandangan keagamaan yang cenderung merendahkan kaum wanita. Wanita dianggap sebagai manusia sekunder karena diciptakan dari tulang rusuk Adam yang merupakan manusia primer atau pertama. Pandangan ini menjadi dasar dari asumsi bahwa wanita merupakan subordinasi dari laki-laki. Ajaran keagamaan yang meremehkan kaum perempuan berkembang disebabkan oleh satu kenyataan bahwa ajaran agama itu dirumuskan dan disebarluaskan dalam struktur masyarakat patriarkhi. ${ }^{3}$

Ketiga, kebanyakan perempuan tidak menginginkan kedudukan sebagai pemimpin, karena perempuan lebih menerima kodratnya sebagai ibu atau perempuan yang dipimpin dan dilindungi oleh laki-laki. Sehingga wajar ketika sebagian besar kedudukan sebagai pemimpin dipegang oleh kaum laki-laki.

Dari ketiga ulasan di atas ternyata yang menyebabkan perempuan termarjinalkan sebagai pemimpin adalah hanya karena unsur budaya yang melekat dan berkembang dalam masyarakat. Dengan demikian, pada prinsipnya siapapun juga, laki-laki atau perempuan yang menduduki posisi pemimpin sama-

${ }^{2}$ Menurut Schmuck yang dikutip oleh Tony Bush \& Marianne Coleman, Manajemen Strategis Kepemimpinan Pendidikan, (Yogyakarta: IRCiSoD, 2008), Cet. II Terj. Fahrurrozi, Hal. 94.

${ }^{3}$ Azizah al-Hibri, et.al., Wanita dalam Masyarakat Indonesia; Akses, Pemberdayaan dan Kesempatan. (Yogyakarta: Sunan Kalijaga Press, 2001), Hal. 283. 
sama merasakan tegangan-tegangan yang terjadi selama memimpin anggota. Untuk menghadapi hal semacam itu pemimpin wanita harus mampu membuka rentang perbedaan gender, membangun harapan-harapan dan membentuk strategi untuk menunjukkan kesejatian eksistensi, seperti kewibawaan, wawasan, empati, daya tawar dan lobi, serta dikenal oleh publik, dengan tidak meninggalkan nilai-nilai keibuan wanita. ${ }^{4}$

Berkaitan dengan kepemimpinan perempuan dalam Islam, hal ini masih menjadi masalah kontroversial. Beberapa faktor yang menjadi penyebab, antara lain adanya nash al-Quran yang secara tekstual mengisyaratkan keutamaan bagi laki-laki untuk menjadi pemimpin, dan adanya nash hadis yang secara lahiriah menunjukkan bahwa suatu kaum tidak akan sejahtera jika dipimpin oleh seorang perempuan.

Secara biologis memang perbedaan jenis kelamin perempuan dan laki-laki dapat terlihat jelas, tetapi dari segi hak dan kewajibannya sebagai manusia, hal ini adalah sama, dengan demikian keberadaan perempuan tidak dapat dipandang sebelah mata, hanya sebagai obyek kebutuhan biologis laki-laki, melainkan merupakan mitra yang sejajar yang saling melengkapi dalam berbagai aspek kehidupan, baik yang bersifat domestik maupun publik.

Budaya Indonesia masih didominasi budaya patriarki. Nilai-nilai dan budaya patriarki yang kuat pada masyarakat Indonesia membuat kesempatan perempuan untuk berperan aktif diberbagai bidang masih harus ditingkatkan. Kesempatan kaum perempuan untuk berprestasi aktif di dalam proses kepemimpinan pendidikan juga masih perlu ditambah. Indonesia memiliki komitmen kuat terhadap pengarusutamaan gender, terlihat dalam komitmen Indonesia terhadap tujuan pembangunan manusia dan dekalarasi Beijing. Hal ini telah membuka kesempatan bagi parlemen Indonesia untuk dapat memiliki wakil-wakil perempuan dalam posisi penting dalam pembangunan, termasuk bidang pendidikan.

Kepemimpinan perempuan dalam perspektif Islam khususnya dalam lembaga pendidikan merupakan hal yang menarik untuk dikaji lebih lanjut, apalagi melalui perspektif tematik al-Qur'an dan Hadits dengan pendekatan sosio-historis

\footnotetext{
${ }^{4}$ Sudarman Danim, Menjadi Komunitas Pembelajar: Kepemimpinan Transformasional dalam Komunitas Organisasi Pembelajaran, (Jakarta: Bumi Aksara, 2005) Cet. Ke 2, Hal. 106.
} 
dan jender. Namun, perlu disadari secara bijak bahwa isu perempuan dekade terakhir ini sangat sulit untuk dipertentangkan dan dipersoalkan kecuali melalui penelitian dengan menggunakan metode yang kontemporer. ${ }^{5}$

Lebih jauh meninjau kepemimpinan perempuan di pesantren, lembaga yang lebih dominan mengajarkan pendidikan agama Islam. Banyak yang meragukan akan kompetensi perempuan dalam kepeimpinanya. Hal ini sejalan dengan adat sosial, kultural dan strukturalnya, bahwa yang biasa dan masyhur menjadi pemimpin di kalangan pesantren adalah laki-laki. Sehingga akan banyak hambatan jika yang ditemukan memimpin adalah seorang perempuan. Sebagai salah satu pusat penyebaran agama Islam Pesantren dapat mencetak peserta didik yang mempunyai kearifan lokal, berjiwa toleransi dan mampu menghasilkan peserta didik yang mampu dalam bidang keagamaan. Pesantren diharapkan mampu membawa perubahan bagi santri dan tradisi masyarakat yang lebih baik di bidang aqidah, ilmu keagamaannya maupun sikap yang mencerminkan nilai-nilai keagamaan. Pondok Pesantren merupakan sebuah asrama pendidikan tradisional, dimana para siswanya tinggal bersama dan belajar di bawah bimbingan seorang guru atau pengasuh Pesantren yang lebih dikenal dengan sebutan (Kyai).

Di dalam pesantren, kiai sebagai pimpinan memiliki karisma karena pengetahuan dan ilmu agamanya. Nyai (istri kiai) yang juga memimpin pesantren putri juga merupakan tokoh masyarakat yang keIslamannya sangat kuat dan disegani. Sekalipun demikian, masih terdapat anggapan di masyarakat luas bahwa keberhasilan nyai dalam memimpin pesantren adalah karena pengaruh dan peran kiai sebagai suaminya, sehingga keberadaan nyai sebagai pemimpin pesantren adalah karena suaminya, bukan karena kemampuannya. Jadi, perempuan tidak dapat eksis karena kemampuannya tetapi masih dikaitkan oleh sesuatu yang lain yang dalam kasus ini adalah suaminya yang berstatus kiai di pesantrennya. ${ }^{6}$

Ditemukan data di kabupaten Bogor pada tahun 2016, hampir 50 pondok pesantren ditutup karena wafatnya sang kyai

5 Abdullah, Irwan, Reproduksi Ketimpangan Gender, Partisipasi Perempuan dalam Kegiatan Ekonomi dalam Dilema Perempuan; Antara Kegiatan Domestik dan Rumah Tangga. Yogyakarta: Aditya Media,1996), Hal. 10. Hal.34.

${ }^{6}$ Faiqoh. Nyai Agen Perubahan di Pesantren. Jakarta: Kucica. 2003. 
dan tidak adanya regenerasi yang dipercaya untuk memegang kepemimpinan pondok pesantren. Hal ini dikarenakan juga karena keidentikan pondok pesantren salafi dengan figur seorang kyai yang mendirikan sekaligus mengajar di pondok tersebut. Hal yang belum disadari oleh masyarakat dan stakeholder pesantren sendiri adalah kemungkinan adanya kompetensi kepemimpinan pada seorang istri kyai (atau yang biasanya di panggil Bu Nyai) yang selalu bersanding dan belajar kepada Kyai setiap waktu, yang bisa dijadikan opsi sebagai penerus perjuangan pesantren $f i$ sabilillah.

Sejalan dengan gerakan emansipasi dan gerakan kesetaraan gender yang intinya berusaha menuntut adanya persamaan hak perempuan dalam berbagai bidang kehidupan, maka secara berkala telah terjadi pergeseran persepsi tentang sosok perempuan. Mereka tidak lagi dipandang sebagai sosok lemah yang selalu berada pada garis belakang, namun seorang perempuan mampu untuk tampil di garis depan sebagai pemimpin yang sukses dalam berbagai sektor kehidupan, yang selama ini justru dikuasai oleh kaum laki laki, tetapi dalam kenyataan nya saat ini kaum perempuan mampu dalam sektor pemerintahan bahkan dalam dalam hal kepemimpinan. Di jaman pembaharuan ini mulai bermunculan perempuan yang ikut andil dalam penyetaraan hak asasi baik sebagai aktivis perempuan, aktif dalam berpolitik, memerankan dirinya sebagai publik figur maupun ikut andil dalam bentuk-bentuk sosial yang setara dengan laki-laki.

Ditemukan di Parung Bogor sebuah Pesantren yang pengasuh utamanya adalah seorang $\mathrm{Bu}$ Nyai. Pesantren $\mathrm{Al}$ Ashriyyah Nurul Iman Islamic Boarding School di Warujaya kecamatan Parung ini dipimpin oleh seorang perempuan yakni Umi Waheeda binti Abdul Rahman, S.Psi, M.Si, Umi tidak hanya mengasuh santri putri, tetapi juga santri putra, serta beliau juga mengelola dan mengembangkan Pondok Pesantren yang berbasis institusi non-profit melalui kewirausahaan sosial.

\section{Dasar Perbedaan Gender dalam Kepemimpinan}

Terdapat perbedaan antara kepemimpinan laki-laki dengan kepemimpinan perempuan. Perbedaan tersebut didasarkan pada lima asumsi sebagai berikut: ${ }^{7}$

7 Wirawan, Kepemimpinan: Teori, Psikologi, Perilaku Organisasi, Aplikasi dan Penelitian, Jakarta: PT Raja Grafindo Persada: 2013, Hal. 503. 
1. Perbedaan Fisik

Secara esensial perempuan fisiknya memang berbeda dengan laki-laki. Perempuan didesain untuk mengandung, melahirkan dan menyusui anak. Laki-laki dilengkapi dengan alat kelamin yang berbeda dengan perempuan dan mempunyai sperma yang berfungsi membuahi indung telur yang ada dalam diri perempuan. Secara alami pertemuan keduanya menghasilkan keberlanjutan perkembangan manusia.

2. Jenis dan Jumlah Hormon

Jenis dan konstalasi hormone yang ada di tubuh perempuan berbeda dengan laki-laki. Misalnya, berdasarkan sejumlah penelitian Kenneth Nowawack (2009) mengemukakan bahwa salah satu hormon perempuan oxytocin merupakan faktor bagaimana perempuan bereaksi menghadapi stress berbeda dalam kepemimpinan. Hormon tersebut merupakan kunci kontribusi logika syaraf (neurological) respons terhadap stress kecenderungan dan menjadi teman (tend and be friend), meningkatnya empati, kepercayaan, dan kolaborasi lebh besar perempuan jika dibanding laki-laki.

3. Otak

Otak manusia terdiri dari otak kanan dan otak kiri. Beberapa artikel menguraikan perbedaan antara otak laki-laki dan otak perempuan. Laki-laki memproses sesuatu lebih baik di otak kirinya sedangkan perempuan kedua belah otaknya mempunyai kemampuan memproses yang sama. Perbedaan ini menjelaskan mengapa laki-laki lebih kuat dalam aktivitas otak kirinya dan pendekatan pemecahan masalah, sedangkan perempuan menyelesaian problem lebih kreatif dan lebih sadar terhadap perasaan ketika berkomunikasi.

4. Psikologi

Ilmu psikologi membedakan spikologi laki-laki dan psikologi perempuan. Perbedaan psikologi ini berdampak pada perbedaan pola piker, sikap dan perilaku perempuan terhadap perilaku laki-laki. Karena kepemimpinan merupakan pola piker dan perilaku pemimpin dalam memengaruhi para pengikutinya, para peneliti banyak meneliti perbedaan pola pikir, sikap dan perilaku perempuan dan laki-laki dalam melaksanakan kepemimpinannya.

5. Persepsi Lingkungan dan Sosial

Masyarakat mempunyai persepsi yang berbeda terhadap perempuan. Perbedaan persepsi mengenai perempuan tersebut pertama, disebabkan karena budaya yang telah berkembang 
dan terbentuk dalam waktu yang lama. Pada masyarakat primitif, perempuan merupakan bagian dari hak miliki lakilaki yang dapat diperdagangkan, ditukar dengan benda lain dan diberikan kepada orang lain. Dalam budaya ini wanita hanya dapat berperan sebagai pemimpin di rumah suaminya, melahirkan dan mengurusi anak-anaknya.

Pendidikan dan pengalaman wanita dalam kegiatan berorganiasi sangat mempengaruhi keinginan untuk memimpin, pola pikir, sikap dan perilaku perempuan dalam memimpin. Pemberian peluang kepada perempuan untuk mengikuti pendidikan tinggi mempengaruhi pola pikir, sikap dan perilaku perempuan dalam kepemimpinan.

\section{Konsep Kepemimpinan Perempuan}

Organisasi yang memiliki kepemimpinan yang baik akan mudah dalam meletakkan dasar kepercayaan terhadap anggotaanggotanya, sedangkan organisasi yang tidak memiliki kepemimpinan yang baik akan sulit untuk mendapatkan kepercayaan dari para anggotanya. Organisasi tersebut akan kacau dan tujuan organisasinya tidak akan tercapai. Para pakar manajemen berbeda pendapat, ada yang sependapat bahwa kepemimpinan itu merupakan suatu bakat, pendapat lain menyatakan bahwa kepemimpinan itu adalah sesuatu yang dapat dipelajari. Padahal pada hakikatnya dalam kehidupan sehari-hari kita dapat melihat bahwa tidak semua orang dikaruniai kemampuan untuk menjadi pemimpin. Menurut Martha Tilaar dan Wulan Tilaar, kepemimpinan dapat dikatakan merupakan suatu perpaduan antara bakat alamiah dan kemampuan yang dapat dipelajari ${ }^{8}$

Perempuan menurut Abdul Qadhir Mansyur diartikan sebagai jenis manusia tertentu yang diciptakan oleh Allah SWT yang memiliki ciri menstruasi, mengandung, melahirkan dan menyusui. ${ }^{9}$

Adapun pengertian perempuan sendiri secara etimologis dalam bukunya Zaitunah Subhan, ${ }^{10}$ Perempuan berasal dari kata Empu yang artinya dihargai. Lebih lanjut Zaitunah menjelaskan

${ }^{8}$ Martha Tilaar dan W.T. Widarto. Leadership Quotient Perempuan Pemimpin Indonesia. Jakarta:Gramedia, 2003, Hal. 6.

${ }^{9}$ Abdul Qadir Manshur, Buku Pintar Fiqih Wanita, Jakarta: Zaman, 2012, Hal. 22-23.

10 Zaitunah Subhan, Qodrat Perempuan Taqdir atau Mitos, Yogyakarta: Pustaka Pesantren, 2004, Hal.19. 
pergeseran istilah dari wanita ke perempuan. Kata wanita dianggap berasal dari bahasa Sansekerta, dengan dasar kata wan yang berarti nafsu, sehingga kata wanita mempunyai arti yang dinafsui atau merupakan objek nafsu. Jadi secara simbolik mengubah penggunaan kata wanita ke perempuan adalah megubah objek menjadi subjek. Tetapi dalam bahasa Inggris wan ditulis dengan kata want atau men dalam bahasa Belanda, wun dan schen dalam bahasa Jerman. Kata tersebut mempunyai arti like, wish, desire, aim. Kata want dalam bahasa Inggris bentuk lampaunya wanted. Jadi, wanita adalah who is being wanted (seseorang yang dibutuhkan) yaitu seseorang yang diingini. ${ }^{11}$ Sementara itu feminisme perempuan mengatakan, bahwa perempuan merupakan istilah untuk konstruksi sosial yang identitasnya ditetapkan dan dikonstruksi melalui penggambaran. ${ }^{12}$ Dari sini dapat dipahami bahwa kata perempuan pada dasarnya merupakan istilah untuk menyatakan kelompok atau jenis dan membedakan dengan jenis lainnya.

Jadi, kepemimpinan perempuan dapat disintesakan sebagai ilmu untuk mempengaruhi orang lain atau kelompok dalam mencapai tujuan organisasi dengan mengerahkan seluruh kekuatan perempuan yang bersifat lemah lembut, tegas, penuh pengayoman, kasih sayang dan mengutamakan prinsip musyawarah untuk mufakat.

\section{Gaya dan Sifat Kepemimpinan Perempuan}

Karakteristik kepemimpinan akan membawa dampak pada kinerja bawahan. Stereotipe perempuan seperti cengeng, kurang percaya diri, tidak mandiri, diduga membawa pengaruh terhadap cara-cara perempuan memimpin. Tilaar mendefinisikan tipe-tipe kepemimpinan perempuan berdasarkan bunga. Sengaja menggambarkan dengan bunga, karena bunga dekat dengan perempuan. Tipe-tipe kepemimpinan digambarkan dengan bunga seperti, bunga mawar, anggrek, melati, cempaka, dan teratai ${ }^{13}$. Definisi tipe-tipe pemimpin sebagai berikut:

${ }^{11}$ Tim Penyusun Kamus Pusat Bahasa, Kamus Besar Bahasa Indonesia, Hal. 448 .

12 Maggie Humm, Ensiklopedia Feminisme, Yogyakarta: Fajar Pustaka, 2002, Hal. 501.

${ }^{13}$ Martha Tilaar, Leadership Quotient Perempuan Pemimpin Indonesia. Jakarta: PT Gramedia Widiasarana Indonesia dan Yayasan Martha Tilaar, 2003, Hal.78-79. 


\section{Tipe Mawar}

Bunga mawar dicirikan dengan akar yang kuat, perforasi daunnya yang manis, dan bunga yang merekah dengan kelopak yang tersusun dalam tatanan proporsional serta duri yang tumbuh di batang dan tangkainya. Kepemimpiann yang dianalogikan seperti bunga mawar dicirikan mempunyai rasa percaya diri yang tebal. Ia mampu menyemarakkan suasana sekitarnya, komunikatif dan populer. Pemimpin dalam klasifikasi ini mempunyai wibawa yang besar, sanggup memberikan kedamaian sekaligus keceriaan bagi pengikutnya namun tetap mengambil jarak.

2. Tipe Anggrek

Bunga anggrek mempunyai pesona yang luar biasa. Pesona anggrek mampu menemani hati manusia dalam berbagai situasi. Sosok pemimpin yang digambarkan oleh tipe anggrek adalah anggun dan elegan. Bunga anggrek yang melambangkan kelangkaan, kemewahan, sekaligus kehangatan. Sosok pemimpin tipe ini memiliki hasrat untuk berbeda, seorang yang sangat ulet, dan sangat menghargai team work.

3. Tipe Melati

Tergolongan tanaman perdu dengan bunga yang kecil, mungil dan low profile. Melati hadir dengan banyak peristiwa dan menjadi simbol kesederhanaan, keindahan dan cinta kasih. Pemimpin yang berada di tipe ini dicirikan dengan sifat yang sederhana, tidak menonjolkan diri dan tidak memanfaatkan kehebatan lahiriah. Prinsipnya menjadi suri tauladan sehingga keputusan yang diambilnya sangat bijaksana.

4. Tipe Teratai

Melambangkan vertilitas, reinkarnasi, juga seksualitas dan kemurnian hidup. Kekhasan dari bunga ini adalah kemampuan untuk hidup di lingkungan yang berlumpur. Pemimpin dalam kategori ini dicirikan dengan tingkah lakunya yang anggun dan santun serta religius. Independensi, keteguhan dan keteduhan seperti teratai yang hidup di lumpur.

5. Tipe Cempaka

Harum cempaka sangat semerbak dengan nuansa misterius. Pemimpin yang masuk dalam kategori ini memiliki sikap penuh tanggung jawab, mampu mengayomi pengikutnya dengan memberikan suri tauladan yang ditunjukkannnya. Kemampuannya menonjolkan diri tidak membuatnya tinggi hati, membuatnya menjadi pemimpin yang flamboyan. 
Pada dasarnya setiap tipe kepemimpinan yang dinampakkan perempuan semuanya mempunyai keunggulan dan kekurangan masing-masing dan itu tidak memberikan perbedaan yang signifikan karena, bagaimanapun gaya yang dinampakkan pemimpin merupakan cerminan dari sikap yang ditunjukkan anggotanya.

\section{Model Pemimpin Perempuan dalam Al Qur'an}

Al-Qur'an juga mengabadikan beberapa nama perempuan, baik disebutkan secara langsung maupun tidak langsung, diantaranya:

\section{1) Ratu Balqis}

Kisah Ratu Saba', ${ }^{14}$ Ratu Balqis diceritakan dalam alQur'an surah an-Naml, kisah mengenai ratu Balqis bermula dari berita yang dibawa oleh burung Hud-hud kepada nabi Sulaiman mengenai sebuah negeri yang dipimpin oleh seorang wanita. Al-Qur'an memang tidak menyebutkan nama pemimpin negeri tersebut, namun buku-buku tafsir telah menjelaskan bahwa nama dari pemimpin negeri itu adalah Balqis.

Negeri Saba' disebut oleh Allah dalam al -Qur'an sebagai negeri yang Baldatun toyyibatun wa robbun ghofur (negeri yang aman, sentosa lagi sejahtera dan mendapat ampunan dari Tuhan). Mendengar ungkapan itu pasti tidak akan jauh dari peran kepemimpinan penguasa negeri Saba' yakni ratu Balqis. Meskipun pada saat itu Ratu Balqis bukan seorang muslimah tapi seorang penyembah matahari namun ia memiliki karakter kepemimpinan yang luar biasa. Balqis adalah sosok pemimpin yang demokratis, penuh empati, adil dan mengutamakan kesejahteraan rakyatnya.

a) Memiliki Pengaruh Besar

Ratu Balqis adalah pemimpin yang sangat dihormati dan ditaati oleh para pengikutnya, kerajaan Saba' yang makmur menggambarkan pemimpin yang memiliki wilayah besar dalam mengatur rakyatnya. Setiap keputusan yang diberikan oleh ratu sangat ditaati oleh rakyatnya. Dikisahkan dalam al -Qur'an ketika para pembesar kerajaan bermusyawarah bersama Ratu dan mengungkapkan

${ }^{14}$ Ratu Saba' bernama, Balqis atau Balqamah'. Lihat Ibn Katsir, al-Kâmil fi al-Târikh, Hal. 231-234. 
pendapatnya, mereka tetap menyerahkan keputusan akhir pada sang Ratu.

b) Demokratis

Dikisahkan ketika Ratu Balqis menerima surat dari nabi Sulaiman, lantas ia kumpulkan para pembesarnya untuk meminta pendapat dalam musyawarah. Sebagaimana dalam Q.S An Naml [27:32]:

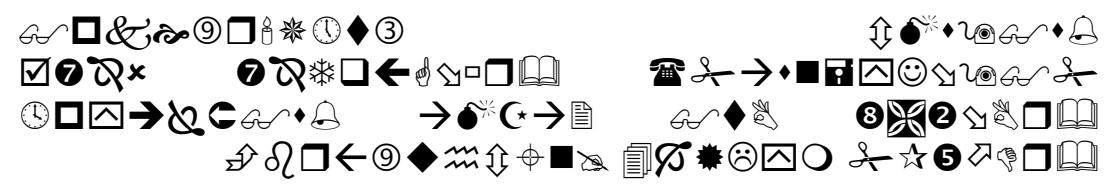

"Balqis berkata: Hai para pembesar, berilah aku pertimbangan dalam urusanku ini, aku tidak pernah memutuskan suatu persoalan sebelum kalian berada di majelisku." Ratu Balqis tidak pernah memutuskan suatu perkara sebelum mendengar terlebih dahulu pendapat dari para pembesar kerajaannya, terlepas dari baik atau tidaknya pendapat yang akan dikemukakan oleh pembesar kerajaan Saba' Ratu tetap akan mendengarnya.

Sikap musyawarah ini sesuai dengan sejumlah studi yang memperlihatkan bahwa perempuan dalam kepemimpinan cenderung lebih demokratik, mereka mendorong partisipasi, berbagi kekuasaan dan informasi, mencoba untuk meningkatkan kemanfaatan bagi pengikutnya, cenderung memimpin melalui pelibatan atau pemberdayaan bawahannya. ${ }^{15}$

c) Cerdas

Kecerdasan ratu Balqis tergambar tatkala ia memberikan pertimbangan kepada para pembesarnya saat menanggapi surat dari nabi Suliman. Para pembesar kerajaan cenderung ingin melakukan perang dan perlawanan terhadap nabi Sulaiman, namun ratu lebih mengetahui akibat yang akan terjadi apabila mereka melawan dengan peperangan. Ratu Balqis mengatakan bahwa "Sesungguhnya Raja-raja apabila menaklukkan suatu negeri, mereka tentu membinasakannya, dan menjadikan penduduknya yang mulia jadi hina; dan demikian yang akan mereka perbuat." ucapan tentang rajaraja adalah berdasarkan pengalaman sejarah masa lampau. Biasanya mereka membunuh atau menawan dan mengusir

${ }^{15}$ Sudaryono, Leadership Teori dan Praktek Kepemimpinan, Jakarta: Lentera Ilmu Cendikia, 2014, Hal. 144. 
para pembesar kerajaan atau pemerintahan yang mereka kalahkan, dengan demikian mereka menghina dan mempermalukannya. ${ }^{16}$.

d) Memperhatikan keselamatan rakyatnya

Ratu Balqis ialah pemimpin yang lebih mengutamakan keselamatan dan kesejahteraan rakyat. Ratu yang menyukai perdamaian karena ia mengetahui dampak peperangan yang akan menhancurkan rakyatnya, maka ia memilih untuk mengirimkan hadiah sebagai balasan atas surat yang diberikan Sulaiman. Kebijakan ini, selain mengacu pada strategi politik yang anggun, juga mencerminkan kepribadian perempuan yang tidak menyukai peperangan, anarkisme, dan lebih memilih menggunakan tipu daya dan cara-cara halus sebelum menggelar kekuatan senjata. ${ }^{17}$

2) Ummahat al Mu'miniin (امّهات المؤمنين)

Islam tidak pernah melarang perempuan untuk aktif dalam bidang politik. Karena itu, pada masa Nabi Saw. kaum perempuan juga ikut terlibat dalam berbagai aktivitas publik atau politik. Di antara aktivitas politik yang dilakukan perempuan pada masa Nabi Saw. seperti yang diceritakan dalam hadis di antaranya adalah: 1) ikut berhijrah ke Habasyah bersama Nabi dan kaum laki-laki, 2) ikut hijrah ke Madinah bersama Nabi dan kaum laki-laki, 3) berbaiat dengan Nabi Saw. seperti yang ditegaskan dalam QS. al-Mumtahanah (60): $12,4)$ ikut peduli terhadap masa depan politik negara yang menganut sistem kekhalifahan, dan 5) ikut menghadapi kezaliman salah seorang penguasa. ${ }^{18}$

Pada masa Nabi Muhammad Saw. kaum perempuan sudah memainkan peran-peran politis dalam rangka menegakkan kalimat-kalimat Allah, seperti melakukan dakwah Islam, ikut berhijrah bersama Nabi, berbai'at kepada Nabi Saw., dan melakukan jihad atau ikut serta dalam peperangan bersama-sama kaum laki-laki. Semua hijrah yang dilakukan Nabi Muhammad Saw. Mengikut-sertakan perempuan di dalamnya. Dalam berbagai peristiwa hijrah,

\footnotetext{
${ }^{16}$ M. Quraish Shihab, Tafsir al-Misbah, Hal. 440.

${ }^{17}$ Asgar Ali Engineer, Perempuan dalam Pasungan, Terj. Agus Nuryanto, Jogjakarta: LkiS, 2003, Hal. 77.

${ }_{18}$ Abu Syuqqah, 'Abd al-Halim. Tahrir al-Mar'ah fi 'Ashr al-Risalah. Alih bahasa oleh Chairul Halim dengan judul "Kebebasan Wanita". Jilid 1-6. Jakarta: Gema Insani Press. Cet. I. 1997, Hal. 78.
} 
perempuan memainkan peran yang cukup penting. Kaum perempuan juga melakukan bai'at bersama kaum laki-laki di hadapan Nabi. Kaum perempuan juga terlibat aktif dalam kegiatan dakwah Islam sehingga banyak perempuan kafir Quraisy yang kemudian menjadi Muslimah karena ajakan mereka. Begitu juga dalam hal jihad atau peperangan, sebagian besarnya menyertakan perempuan di dalamnya. Meskipun peran mereka sebagai pendukung atau pendamping, tetapi peran mereka sangat penting dan menanggung resiko yang sama seperti halnya laki-laki. Dalam mengatur urusan pemerintahan, perempuan belum banyak berperan pada masa ini, mengingat Nabilah yang memiliki otoritas tertinggi. Namun peran ummahat al-mu'minin cukup besar dalam memberikan masukan-masukan kepada Nabi dalam memutuskan berbagai kebijakan kenegaraan.

Di antara problem yang dihadapi perempuan dalam melakukan peran-peran politis pada masa Nabi adalah tekanan kaum kafir Quraisy Makkah di awal dakwah Islam, kelemahan fisik mengingat begitu beratnya aktivitas yang dilakukan untuk berhijrah dan berjihad misalnya, serta kehilangan keluarga dan harta serta kampung halaman. Namun demikian, problemproblem seperti ini tidak menghalangi peran-peran perempuan di dunia politik. ${ }^{19}$

Sebaik-baiknya istri adalah istri-istri yang mendampingi Nabi Muhammad Saw. Mereka adalah tempat kehormatan dan kemuliaan dalam agama dan ketakwaan. Mereka menyaksikan turunya wahyu dan penerapan amal dalam Islam dengan kedua sumber, yaitu: Al-Qur'an dan As-Sunnah. Dalam kehidupan mereka yang dijalaninya banyak pelajaran pelajaran dan nasihat-nasihat yang patut diteladani.

3) Asiyah (Isteri Fir'aun)

Asiyah Binti Muzahim adalah isteri kesayangan Fir'aun seorang raja yang kafir dan dzalim. Dia menjadi isteri Fir'aun setelah Fir'aun melakukan pemaksaan untuk menjadikannya sebagai isteri. Fir'aun bisa memperisteri Asiyah merupakan bentuk penjajahan dan penindasan. Ketika Fir'aun dalam kesendirian karena ditinggal mati oleh isterinya, ia mendengar kabar bahwa ada gadis jelita keturunan keluarga Imran yang

${ }^{19}$ Marzuki dan Suharno, Keterlibatan Perempuan dalam Bidang Politik pada Masa Nabi Muhammad SAW dan Masa Khulafaur Rasyidin (Suatu Kajian Historis) Jurnal Penelitian Humaniora, Vol. 13, No. 1, April 2008: 7794, Hal. 90 
bernama Asiyah. Fir'aun tergoda oleh berita itu, karenanya ia mengutus Haman untuk melamarnya. Lamaran itu ditolak oleh Asiyah.

Di bawah ancaman Fir'aun sang raja yang dzalim itu, Asiyah terpaksa menerima lamaran Fir'aun dengan syaratsyarat. Pertama, Fir'aun harus membebaskan orang tuanya. Fir'aun harus membuatkan rumah untuk ayah dan ibunya, yang indah lengkap dengan perabotannya. Kedua,Fir'aun harus menjamin kesehatan, makan, minum kedua orang tuanya. Kalau kedua syarat itu dipenuhi, maka Asiyah bersedia menjadi isteri Fir'aun. ${ }^{20}$

Dalam acara-acara tertentu Asiyah hadir bersama Fir'aun, tapi dia tidak bersedia tidur bersama Fir'aun. Sekiranya permintaan permintaan tersebut tidak disetujui, Siti Asiyah rela mati bersama ibu dan bapaknya. Akhirnya Fir'aun menyetujui syarat-syarat yang diajukan oleh Asiyah. Fir'aun lalu membebaskan kedua orang tua Asiyah. Siti Asiyah pun tinggal dalam kemewahan istana bersama Fir'aun.

Walaupun Asiyah tinggal dalam kemewahan istana, ia tetap patuh terhadap perintah Allah dan tetap melaksanakan ibadah kepada Allah SWT. Di malam hari Asiyah selalu bangun melaksanakan shalat malam (menurut syari'at Nabi Ibrahim) bermohon kepada Allah agar kehormatannya tidak disentuh oleh raja kafir Fir'aun. Untuk menjaga kehormatannya, Allah SWT menciptakan iblis yang sangat serupa dengan Asiyah. Dialah iblis yang setiap malam tidur dan bergaul dengan Fir'aun. Jadi meskipun Fir'aun mempunyai istri Asiyah, dia tiap malam bercintanya dengan iblis. ${ }^{21}$

Ketika Fir'aun mengetahui bahwa isteri kesayangannya bertuhankan Allah, sangat murkalah raja yang dzalim itu. Ia memerintahkan agar Asiyah isteri kesayangannya itu dibenamkan kakinya ke dalam tanah dan di atasnya diletakkan pasak dari beton agar ia mengingkari Allah dan menjadikan Fir'aun sebagai tuhannya, tetapi Asiyah tetap dalam keyakinannya dan berdoa kepada Allah sebagaimana yang tersebut dalam Alquran surah at-Tahrim ayat 11. 344

${ }^{20}$ Tim Baitul Kilmal, Ensiklopedi Pengetahuan Alquran dan Hadis, Hal.

${ }^{21}$ Umar Sulaiman Abdullah Al-Asyqar 14 Wanita Mulia dalam sejarah Islam (terjemahan dari Nisa' Lahunna Mawaqif), Cet. 5; Pustaka Yassir, 2008, Hal. 211. 
"Dan Allah membuat isteri Fir'aun perumpamaan bagi orang-orang yang beriman, ketika ia berkata: Ya Tuhanku, bangunkanlah untukku sebuah rumah di sisi-Mu dalam surga dan selamatkanlah aku dari Fir'aun dan perbuatannya dan selamatkanlah aku dari kaum yang dzalim. ”.

Doa Asiyah didengar oleh Allah SWT dan mengutus malaikat kepada Asiyah yang sedang tersiksa untuk memperlihatkan tempatnya kelak di dalam surga. Akhirnya Asiyah binti Muzahim turunan Nabi Ishak as, gugur di tangan tentara Fir'aun sebagai syuhada yang mempertahankan iman.

\section{Gaya Kepemimpinan Umi Waheeda}

Gaya kepemimpinan diduga kuat mempengaruhi penerimaan bawahan terhadap atasan perempuan. Melalui 12 pertanyaan masing-masing gaya kepemimpinan akan dibagi menjadi tiga kategori yaitu tinggi, sedang dan rendah. Berikut merupakan hasil penelitian penulis dari 50 informan mengenai gaya kepemimpinan Umi Waheeda. Survey menunjukkan bahwasannya para responden paling dominan menerima gaya kepemimpinan Umi dengan karakteristik bunga Melati sebesar 92\% (46 orang). Hal ini menggambarkan bahwa sebagai pemimpin Umi menunjukkan kesederhanaan, suri tauladan dan bijaksana. Respon yang tinggi diberikan untuk pemimpin dengan ciri kepemimpinan yang ulet, suri tauladan, bijaksana dan flamboyan.

Ciri kepemimpinan yang ulet menggambarkan bahwa Umi menunjukkan dalam kepemimpinannya sebagai seorang yang sangat giat bekerja mengusahakan keberlangsungan institusi melalui bermacam strategi. Ciri kepemimpinan yang suri tauladan menggambarkan bahwa pemimpin mampu memberikan contoh yang terbaik serta memberikan pengajaran kepada para bawahan bagaimana berhubungan baik dengan orang lain. Selebihnya diterangkan bahwa pemimpin itu harus memiliki suri tauladan yang baik krena hakikat kepemimpinan dalam pandangan Islam adalah amanah yang harus dijalankan dengan baik dan dipertanggung jawabkan bukan saja di dunia tapi juga di hadapan Allah nanti di akhirat.

Firman Allah SWT dalam Q.S Al-Ahzab [33:21] tentang suri tauladan yang baik yaitu. 


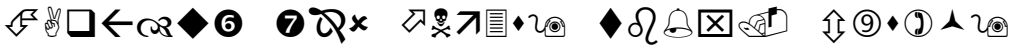

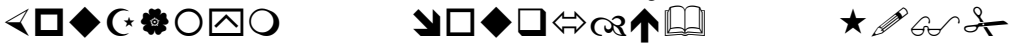
1 a f

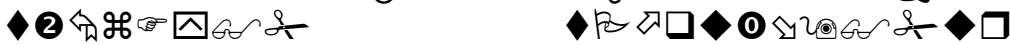

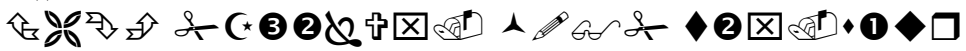

Sesungguhnya telah ada pada (diri) Rasulullah itu suri teladan yang baik bagimu (yaitu) bagi orang yang mengharap (rahmat) Allah dan (kedatangan) hari kiamat dan Dia banyak menyebut Allah.

Ciri kepemimpinan yang Flamboyan adalah tidak pernah memamerkan kekayaan dan boros walaupun pumya materi yang cukup serta gemar berbagi untuk orang lain dengan ikhlas. Hal ini sesuai dengan Q.S. Al-Israa ayat 26-27

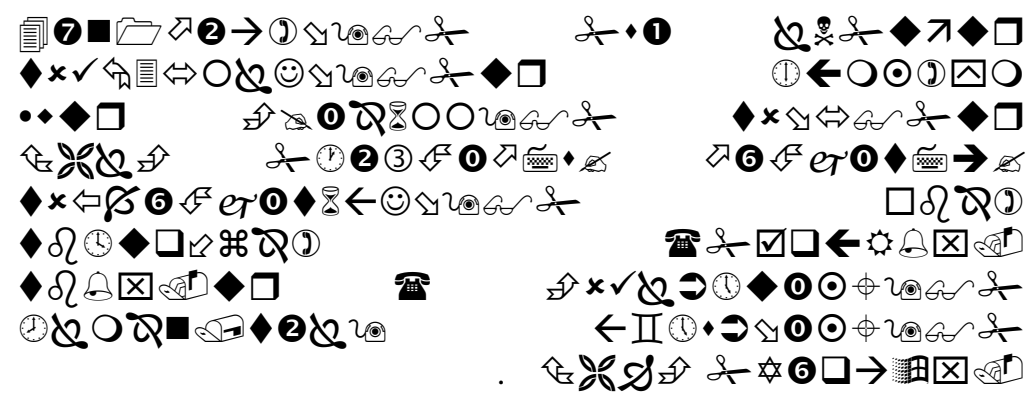

Dan berikanlah kepada keluarga-keluarga yang dekat akan haknya, kepada orang miskin dan orang yang dalam perjalanan dan janganlah kamu menghambur-hamburkan (hartamu) secara boros. Sesungguhnya pemboros-pemboros itu adalah saudara-saudara syaitan dan syaitan itu adalah sangat ingkar kepada Tuhannya.

\section{Karakteristik Kepemimpinan Umi Waheeda}

Dalam teori Feminisme Liberal berasumsi bahwa pada dasarnya tidak ada perbedaan antara laki-laki dan perempuan. Karena itu perempuan harus mempunyai hak yang sama dengan laki-laki. Hal ini mampu dibuktikan oleh Umi Waheeda sebagai perempuan pemimpin.

Eksistensi kepemimpinan perempuan akan mendapat pengakuan setelah terbukti melalui prestasi-prestasi yang diraihnya. Umi Waheeda telah mampu menjamin keberlangsungan pesantren dengan ribuan santri tanpa pungutan biaya bi idznillah. Melalui kepemimpinan beliau institusi ini tetap survive dan mampu berdikari secara mandiri dengan sistim 
perekonomian yang dibangun oleh sang suami, Abah Saggaf bin Mahdi dengan dikembangkan secara produktif sehingga mampu menopang seluruh biaya operasional harian pesantren. Berikut penulis uraikan karakteristik Umi Waheeda secara unik yang belum pernah penulis temui pada kepemimpinan laki-laki sebelumnya:

1. Umi Waheeda Perempuan Pemimpin yang tangguh

Dalam shahabiyah kita mengenal para wanita sholehah pendamping suami, yaitu Siti Khadijah. Beliau seorang exporter dan Importir yang seluruh penghasilannya diserahkan dalam dakwah Rasulullah SAW. Qudwah Hasanah figure Siti Khotidjah, yaitu pedagang, pendamping suami dan setia dalam suka dan duka bersama Rasulullah SAW kami yakni ada pada Umi Waheeda, S. Psi. M.Si binti Abdurrahman, beliau mewarisi sifat-sifat Siti khodijah tersebut. Umi Waheeda adalah seorang wanita sholehah yang memiliki puluhan sektor usaha, beliau setia terhadap Abah sang suami tercintanya, selalu berkomitmen menutup auratnya, tak pernah tertinggal sholat tahajjud dan dhuhanya, energik, ekspresif yang istimewanya lagi beliau terlahir di Singapura, tetapi hidupnya untuk melayanid an mendidik rakyat Indonesia. Ide briliannya kini telah membentuk kampung peradaban Indonesia (Nurul Iman).

Perempuan pemimpin pun menjadi tempat berbagai curahan masalah para karyawannya. Begitu pula dengan apa yang disampaikan oleh salah satu karyawan Umi Waheeda: "Iya, kalau ada hal-hal yang sifatnya tidak sesuai dengan normatif beliau selalu mengingatkan. Dan kamipun ketika ada suatu ketidaksesuaian yang ada, langsung mengkonsultasikan dan meminta arahan kepada Umi. Umipun akan mengarahkan dan memberi putusan terhadap suatu perkara yang tidak bisa dilakukan oleh para pimpinan sekolah yang ada di Yayasan. Umi selalu menomorsatukan koordinasi yang ada di pesantren. Semua kebijakan, putusan, dan segala informasi ada dalam satu alur yaitu kepada Umi Waheeda selaku pembina pesantren.

Perempuan pemimpin juga sering kali memberikan perhatian dan mengkoordinir karyawannya dengan baik. Diantara banyak pesantren di Indonesia, tetapi mungkin hanya sedikit yang memberi peluang dan sampai bisa bertahan dengan dipimpin oleh seorang perempuan. Dan hal ini tentu tidak mudah, karena banyak perempuan disana yang telah 
lama mendampingi suaminya sebagai Kyai dan tentu mempunyai keilmuan dan pengetahuan yang tinggi tetapi pada kenyataannya banyak pesantren yang harus ditutup dan ditinggalkan santri-santrinya karena kepergian sang Kyai. Dan menurut Umi untuk menjadi pemimpin tidak hanya dibutuhkan keilmuan saja yang tinggi tetapi harus ada open minded.

2. Pemimpin yang Produktif

Tidak semua pemimpin mampu menjadi seseorang produktif seperti yang dilakukan Umi Waheeda. Rata-rata dari mereka akan terlihat produktivitasnya melaluinya keuletan bekerja, tetapi bukan dalam hal produksi. Hal ini juga bukan semata-mata ide murni dari Umi langsung, hal-hal ini telah dikonsep oleh Almarhum suami Umi melalui unit usaha yang pada awalnya hanyalah sebagai vocasional education (pendidikan keterampilan), dan melalui tangan terampil Umi, beliau mampu memaksimalkan fungsi unit-unit usaha sebagai penopang operasional pesantren. Umipun menjelaskannya sebagai berikut:

Memang ciri umum yang membedakan antara pemimpin laki-laki dan dan perempuan adalah sifat reproduksi. Perempuan ditakdirkan untuk mampu berkembang biak dan mampu menjadikan hal yang sedikit menjadi lebih banyak. Perempuan selalu mampu untuk berhemat bahkan menyisihkan lebih banyak untuk kebutuhan yang lain. Inilah yang penulis sebut produktif. Sebagaimana penuturan Umi di atas.

Melalui produksi yang dilakukan di pesantren inilah juga yang menjadikan pesantren Nurul Iman sebagai rujukan dari beberapa pesantren dalam kemandirian yayasan serta penguatan ekonomi pesantren melalui kewirausahaan sosial yang terbangun. Umi merasa bahwa sistem produksi inilah yang akan membawa penguatan

Akan lebih berkah jika kita memakan dari apa yang dihasilkan oleh tangan kita sendiri. Dan keberkahan itupun akan muncul lebih banyak lagi ketika kita mampu membagi kebahagian untuk orang yang banyak. Karena ketika pesantren mampu mengumpulkan orang yang banyak, maka Allah juga akan limpahkan rizki dan keberkahan yang banyak pula, sebagaimana apa yang dipahami Umi berikut:

Sejak awal kemunculannya, Al Ashriyyah Nurul Iman hadir sebagai Non-profitable Institution karena keprihatinan atas kirsis multidimensi yang melanda masyarakat Indonesia. 
Melalui langkah sistematis dan progressif, pesantren ini mampu mengintegrasikan keilmuan agama dan Umum. Lebih dari itu, Nurul Iman juga menyelenggarakan Pendidikan life skill melalui beberapa Lembaga kursus dan pelatihan yanga da di dalamya. Pendidikan life skill juga diperoleh santri dengan mengikuti program magang (internship) di beberapa unit usaha yang mulanya hanya sebagai pembelajaran terapan kini menjadi sumber pendanaan utama untuk keberlangsungan pesantren yang berdiri sejak tahun 1998 ini.

Dengan menerapkan kurikulum management system yang terstruktur serta dibarengi dengan pengelolaan secara professional, unit-unit usaha pesantren Nurul Iman terus berkembang dan menggurita. Hingga saat ini tercatat lebih dari 31 unit usaha mandiri yang dimiliki Nurul Iman dan dikelola langsung oleh santri. Melalui unit-unit usaha pesantren yang bergerak dalam beberapa bidang, seperti manufaktur, jasa, dan niaga (perdagangan), Nurul Iman mampu bertahan secara mandiri tanpa harus mengandalkan donasi dari pihak lain. Pabrik roti adalah perusahaan internal yang cukup diandalkan untuk mencukupi makan santri sehari hari selain dari 33 sektor wirausaha lain yang menjadi andalan.

3. Inisiator Pendidikan Gratis yang Mandiri

Hasil temuan pertama yang menjadikan penelitian ini menarik dan berbeda dengan kepemimpinan yang lain adalah adanya karakter Umi Waheeda yang secara bersama-sama dengan sang Suami menginisiasi pendidikan gratis bebas pungutan serta mandiri. Yang menjadikan mandiri dari pesantren ini adalah sejak dipimpin oleh Umi Waheeda, pesantren ini tidak pernah sekalipun bergantung oleh uluran donatur demi keberlangsungan operasional. Karena Umi mempunyai prinsip demi menjaga muru'ah atau dicnaty muslim selayaknya lembaga pendidikan harus mempunyai usaha yang mandiri sehingga tidak bergantung pada donatur. Sebagaimana petikan berikut:

Mengacu kepada Rasulullah sebagai living model, Umi memperkenalkan sistem wirausaha sosial untuk membantu kemandirian institusi pendidikan. Social enterpreneuship ini dipilih Umi Waheeda sebagai bentuk perubahan progresif AlAshriyyah Nurul Iman, yang dapat berdiri didukung oleh wirausaha tanpa mengandalkan donatur. Kondisi ini merupakan keterlibatan langsung suatu bisnis untuk masyarakat tanpa adanya imbalan bagi para pelaku wirausaha 
sendiri. Hal ini dimaksudkan bahwa bentuk wirausaha yang dibentuk dalam pesantren guna mendukung seluruh operasional inti yakni Free and Quality Education. Sehingga tujuan awal untuk membantu kaum dhuafa dan memberikan pencerahan dengan spirit Islam sebagaimana Rasul contohkan dapat tercapai.

Konsep bisnis ini merupakan sebentuk amal dan bukan profit Corporation. Namun, baik Non-profit Organization atau social entrepreneurship tidaklah menomorsatukan uang (keuntungan) karena keuntungan atau laba hasil usaha justru diperuntukkan untuk Non-profit institution, dalam hal ini adalah biaya hidup santri. Sebab itu sistim yang dibentuk dari pesantren Nurul Iman ini adalah Non-profit organization/ Institution dan sekaligus juga menjalankan social entrepreneurship.

Hal ini dapat ditarik dari teladan Rasulullah dalam kiprah dakwahnya, modal utama (capital) bisnis bukanlah uang karena pemidal awal Rasulullah adalah Sayyidah Khadijah R.A. pada awalnya, beliau hanya menjalankan modal orang lain dengan sistim upah (free Based) dan bagi hasil (profit Sharing) sehingga profesi Rasul adalah Mudharib (pengelola) modal. Setelah menikah dengan Sayyidah Khadijah, Rasulullah menjadi manajer sekaligus mitra kerja istrinya. Memasuki usia tigapuluhan, beliau menjadi investor dan Bussiness owner dan mulai memiliki waktu untuk memikirkan kondisi masyarakat. Kekayaan Rasul dari hasil usaha inilah yang nantinya beliau gunakan untuk kepentingan ummat setelah kenabiannya karena boikot terhadap banu Hasyim dan Abdul Mutholib oleh kaum kafir musrik. Inilah social entrepreneurship yang dilakukan Rasul pada masa lampau. ${ }^{22}$

4. Pemimpin yang Penyantun

Banyak pemimpin di dunia ini yang mampu menjadi seorang penyantun, baik laki-laki maupun perempuan. Tetapi, dalam tulisan ini penulis memberikan garis tegas bahwasannya arti penyantun disini adalah mampu memberikan santunan dan kasih sayang kepada kaum dluafa baik secara materiil maupun spiritual dengan ikhlas dan tanpa batasan waktu. Hal ini telah dilakukan Umi dan Abah dari sebelum didirikannya Pesantren Al Ashriyyah Nurul Iman, dan semakin istiqomah-lah hal

${ }^{22}$ Miss Fukuyama, "Al-Ashriyyah Nurul Iman an Example of Non-profit Organization and Social Enterpreneurship", Majalah Nurul Iman Volume 12 tahun 2013. 
tersebut setelah terbangunnya pesantren. Umi yang dulunya bersama Abah dan sekarang masihlah sama setiap harinya harus memberikan santunan dalam bentuk menggratiskan biaya pendidikan, logistik serta kesehatan ribuan santrinya. Tak kurang dari 10 Ton beras, 5 Ton Singkong dan 30 tong sayur setiap harinya disediakan Umi untuk konsumsi para santrinya. Dalam hitungan kasar pertahunnya Umi harus menyiapkan kurang lebih $23 \mathrm{M}$ untuk kebutuhan pendidikan, kesehatan, logistic serta gaji karyawannya. Semuanya diberikan Umi secara cuma-cuma. Umi tidak pernah meminta atau memungut biaya tersebut kepada santri atau wali santrinya.

5. Pemimpin yang Progressif

Kiprah kepemimpinan yang dilakukan Umi dalam delapan tahun terakhir ini terbilang membawa Nurul Iman dalam progress yang luar biasa. Dalam pandangan penulis Umi mampu menuntaskan tunggakan-tunggakan administrasi yang belum terselesaikan setelah kewafatan sang Suami. Umi mampu menstabilkan aktivitas pesantren setelah ketiadaan pendiri pertama pesantren dengan baik. Umi mampu melanjutkan estafet menejerial pesantren yang sangat rumit yang telah diwariskan kepadanya dengan tatanan manajemen yang sangat apik. Serta terbangunnya beberapa gedung baru untuk para santri. Hal ini berbanding terbalik dengan realita, yang biasanya pesantren ditinggal sang pimpinan laki-laki akan mengalami kemunduran bahkan kemusnahan tetapi di pesantren yang Umi pimpin justru mengalami kemajuan yang pesat. Hal ini yang memberikan simpulan kepada penulis untuk menyebut Umi sebagai pemimpin yang progressif.

Dilihat sifat kepemimpinan pada Umi waheeda adalah the iron maiden. Pada awal kepemimpinannya bersama Abah di pesantren memang beliau tidak secara "besi" dalam bertindak, namun seiring dengan tuntutan waktu membuat beliau menjadi sosok tangguh dan pekerja keras sehingga Umi giat dalam mengusahan keberlangsungan operasional pesantren yang sekrang dipimpinnya. Dengan sifat the iron maiden ini, Umi Waheeda secara langsung mengajak pegawainya untuk bekerja dengan giat, keras dan ikhlas demi mewujudkan cita-cita bersama memberikan pendidikan berkualitas di Nurul Iman yang gratis sampai Kiamat.

Umi sangat giat memperkenalkan Pesantren Nurul Iman kepada publik ketika mendapati kesempatan untuk 
memberikan ceramah, undangan, presentasi maupun kunjungan-kunjungan yang rata-rata adalah pesantren kolega yang mengikuti program Bank Indonesia dalam penguatan ekonomi pesantren. Setelah tahun 2016 Kementerian Agama menunjuk Pesantren Nurul Iman sebagai pusat entrepreneurship untuk lembaga pendidikan Islam di Indonesia, selanjutnya pada September 2017 pemerintah melalui Bank Indonesia memilih Nurul Iman sebagai rujukan entrepreneur dalam bidang pengolahan sampah dan filter air minum bersih (drinkable water treatment).

Sebagaimana dilansir dalam Majalah Nurul Iman Volume ke-14 bahwasannya BI memberikan kepercayaan sepenuhnya kepada Nurul Iman adalam mengelola beberapa pesantren seIndonesia untuk mencontoh program internship yang telah dilaksanakan oleh Nurul Iman. Pesantren-pesantren tersebut diantaranya adalah Pondok Pesantren An-Nahl Bogor, Pondok Pesantren Al-Ishlah Bobos, Pondok Pesantren Cikoneng, dan Pondok Pesantren Nadwatul Banin wa Banat Buntet, dan tahun ini hingga ke Pesantren Gontor untuk Unit daur ulang sampah serta Pondok Pesantren Raudhatul Muta'alimin untuk Unit drinkable water treatment. ${ }^{23}$ Program tersebut terus berkembang sesuai harapan pemerintah, dalam hal ini Bank Indonesia berharap agars semua pesantren se-Indonesia menerapkan sistem yang telah terlaksana di pesantren Nurul Iman. Hal inipun disampaikan juga oleh Gubernur Bank Indonesia, Perry Warjiyo dalam kunjungannya di pesantren Nurul Iman tanggal 7 Agustus 2018 dalam program "BI Mengajar."

\section{Peranan Umi Waheeda dalam Pengelolaan Pesantren Al - Ashriyyah Nurul Iman}

Dalam pengelolaan dan keberlangsungan operasional pesantren tidak akan terpenuhi dan sempurna tanpa peran serta Umi Waheeda, pimpinan tertinggi Yayasan Al-Ashriyyah Nurul Iman. Banyak peranan yang dimainkan Umi sebagai pengasuh serta pimpinan pesantren dalam menjaga stabilitas pesantren dan memajukannya. Sebagaimana berikut penulis sajikan.

1. Pembiaya Utama

${ }^{23}$ Subaiki Ikhwan, Al-Ashriyyah Nurul Iman Menjawab Tantangan Dunia Kerja, Majalah Nurul Iman Volume ke-14, tahun 2018 
Sebagaimana diketahui oleh para stakeholder pesantren, bahwa operasional finansial pesantren baik pendidikan, kesehatan, makan dan tempat tinggal ditanggung oleh pemilik pesantren yaitu Umi Waheeda. Tidak ada deretan donatur tetap ataupun institusi yang dengan istiqomah tiap bulannya memberikan donasi dan bantuan untuk pesantren, pun juga pungutan uang gedung atau biaya SPP. Umi Waheedalah yang menanggung semua biaya yang dibebankan kepada pesantren dalam memunuhi kebutuhan santri setiap harinya. Hal yang dilakukan Umi ini adalah melanjutkan perjuangan dari sang Suami, yaitu Habib Saggaf pendiri pesantren yang mencetuskan pendirian pesantren gratis ini. Tercatat berapa milyar yang harus dihabiskan yayasan dalam pemenuhan kebutuhan pendidikan dan logistic santri per tahunnya. Semua dicover oleh Umi Waheeda tanpa pamrih sedikitpun. Umi ikhlas melakukan semua itu demi pendidikan anak-anak muslim agar senantiasa terpelihara agamanya dan semakin meningkat keimanannya. Juga agar anak-anak yang kurang mampu tersebut mempunyai skill dan pendidikan agar mampu menjadi pendidik dan pengusaha sukses yang pada akhirnya mampu membuka peluang usaha seluas-luasnya dan mampu mengentaskan kemiskinan dan kebodohan yang ada di masyarakat dimana mereka kembali di daerahnya.

2. Pendidik

Peran Umi Waheeda di dalam pesantren adalah sebagai pendidik. Umi mengajar para mahasiswa di kampus dalam materi berbahasa Inggris. Umi meluangkan untuk mengajar di hari Ahad setiap minggunya. Lebih dari pengajaran, Umipun mendidik semua santri melalui kurikulum yang telah dipatenkan di pesantren. baik kurikulum yang mengikuti dinas, pembelajaran kitab dan pemberdayaan santri melalui wirausaha. Pendidikan yang diberikan di pesantren diberikan dengan serius guna membentuk kepribadian yang berkeilmuan tinggi dan berkeahlian bagi santri yang telah lulus. Umi memperhatikan setiap gerakan dan kejadian di luar kelas yang dilakukan oleh santri. Memberikan teladan kepada santri dan memastikan keadaan santri dalam keadaan baik-baik saja. Dan pada event-event tertentu ketika perkumpulan santri, Umi akan memberi sambutan kepada tamu seraya menyelipkan pesanpesan moral kebaikan dan akidah keagamaan kepada santri tentang pentingnya menjadi pemimpin yang berjiwa nubuah 
yang sidiq, amanah, tabligh dan fathonah serta jujur dan ikhlas untuk agama Allah.

Dan ketika menjadi pembina upacara Umi akan membangkitkan semangat nasionalisme para santri, agar untuk tetap menjaga keutuhan NKRI dan mempunyai sikap juang yang tinggi demi bela Negara Indonesia. Di setiap kesempatan Umi selalu memberikan pengajaran dan didikan baik untuk para santri yang menjadi peserta didik di sekolah maupun santri yang telah berkhidmat untuk mengajar di pesantren. Hal inilah yang akan memotivasi semua kalangan di pesantren untuk termovitasi dalam belajar dan menuntut ilmu.

3. Pengasuh

Umi Waheeda mempunyai peran yang sangat sentral di dalam pesantren Nurul Iman yaitu sebagai pengasuh yayasan. Umi adalah pengasuh kedua setelah mendiang Abah meninggalkan dunia delapan tahun lalu. Sebagai pengasuh pesantren di generasi kedua Umi terlihat mampu menghadirkan stabilitas pesantren. Terlihat tidak banyak dari jumlah santri yang menyusut setelah kewafatan sang Kyai seperti di pesantren lain. Perkembangan dan pembangunan yang ada di pesantrenpun berjalan progressif dalam kendali Umi Waheeda. Dan yang terpenting visi dan misi pesantren masih terjaga oleh kepemimpinan Umi. Tekad dan komitmen yang dibagun oleh Habib Saggaf untuk memberikan pendidikan gratis senantiasa dilanjutkan oleh Umi Waheeda, tanpa bergeser sedikitpun.

Umi memberikan pengasuhan secara menyeluruh baik kepada para pegawai, manajer, maupun santri-santri di bawahnya. Dari situlah terlihat pola pengasuhan yang dilakukan Umi melalui pendekatan yang lebih humanis. Terlihat Umi adalah seorang pendengar yang baik yang mau mendengar keluhan atau permasalahan yang dihadapi oleh para santrinya. Dan Umi mau memperbaiki kekurangan bahkan menyempurnakan apa yang menjadi kekurangan pesantren. Umi memberikan solusi dan keputusan yang diajukan kepadanya dengan cepat dan tegas. Sehingga tidak ada keraguan bagi para pengurus di bawahnya untuk mengambil sikap dan menyelesaikan banyak hal. 


\section{DAFTAR PUSTAKA}

Al Hamdani, Djaswidi. Pengembangan Kepemimpinan Transformasional pada Lembaga Pendidikan Islam. Bandung: t.Tp. 2005.

Ali, Atabik dan Ahmad Zuhdi Muhdlor. Kamus Kontemporer: Arab-Indonesia. Yogyakarta: Multi Karya Grafika. 1996.

al-Mawardi, Abu Al Hasan. Al-Ahkamu Al-Sulthaniyah wa AlWilayat al-Diniyyah. Kairo: Al Maktabah at Taufiqiyah. 1978.

al-Qaradlawi, Yusuf. 1996. Markaz alMar'ah fi al-Hayat alIslamiyah. terj Asy'ari Khatib. Cairo: Maktabah Wahbah.

Al-R̄̄ghib al-Asfahōnĩ. Al-Mufradat fi Gharib al-Qur'an. Bairut: Dar al-Ma'rifah. tth.

Ambawati dan Aida Husna. "Manajemen Pesantren Responsif Gender: Studi Analisis di Kepemiminan Nyai Pesantren di Kabupaten Pati”. Palastren: Jurnal Studi Gender: 2016

Amrullah A,bdul Malik Abdul Karim. Tafsir al-Azhar. Juz IV. Jakarta: Pustaka Panjimas. 1984.

Anasom. Kyai. Kepemimpinan dan Patronase. Semarang: PT. Pustaka Rizki Putra. 2007.

Andri, Sofia Rosdanila. "Argumen Penafsiran Tekstualis versus Kontekstualis tentang Kepemimpinan Perempuan”. Refleksi: 2014

Arbaningsih, Dri. Kartini Dari Sisi Lain Melacak Pemikiran Kartini Tentang Emansipasi Bangsa.

Arifin, Muzayin. Filsafat Pendidikan Islam. Jakarta: PT. Bumi Aksara. 2010.

Arifin. Kepemimpinan dan Motivasi Kerja. Yogyakarta: Teras. 2010. 
as-Sya'rawi, Syeikh Mutawally. Fikih Perempuan Muslimah; Busana dan Penghormatan atas Perempuan. sampai Wanita Karier. diterjemahkan oleh Yessi H.M. Basyaruddin dari judul Fiqh al Mar'ah al Muslimah. Jakarta: Amzah. 2009.

Azizah al-Hibri. et.al, Wanita dalam Masyarakat Indonesia; Akses. Pemberdayaan dan Kesempatan. Yogyakarta: Sunan Kalijaga Press. 2001.

Bahar, Ahmad. Biografi Politik Megawati Soekarnoputri 1993 -1996. Yogyakarta: PT Pena Cendekia. 1996.

Bass, Bernard M. Bass \& Stogdill's. Handbook of Leadership: Theory. Research \& Managerial Application. New York: The Free Press. 1990.

Bass, Bernard M. Leadership Performance Beyond Expectations. New York : Academic Press. 1985.

Bush, Tony \& Marianne Coleman. Manajemen Strategis Kepemimpinan Pendidikan. Yogyakarta: IRCiSoD. Cet. II. 2008.

Fachrudi, Indra. Soekarto. dkk. Pengantar Kepemimpinan Pendidikan. Surabaya: Usaha Nasional. 1983.

Faiq, Abdullah. Analisis terhadap Kepemimpinan Perempuan dalam Birokrasi Pemerintahan Studi terhadap Kepemimpinan Perempuan di Kabupaten Tuban Jawa Timur. Tesis Universitas Airlangga. Jawa Timur: t.p. 2004. tidak diterbitkan.

Faiqoh. Nyai Agen Perubahan di Pesantren. Jakarta: Kucica. 2003.

Fakih, Mansour. Analisis Gender dan Transformasi Sosial Cet. IX. Yogyakarta: Pustaka Pelajar. 2005.

Farida, Rokhila. Faktor-faktor yang Mempengaruhi Persepsi Perempuan Sunda Terhadap Kepemimpinan Perempuan Kasus Desa Cikarawang. Kecamatan Dramaga. 
Kabupaten Bogor. Jawa Barat.Skripsi. Program Studi Komunikasi dan Pengembangan Masyarakat. Fakultas Pertanian. Institut Pertanian Bogor. 2005.

Fatah, Nanang. Landasan Mangement Pendidikan. PT Remaja Rosda Karya : Bandung. 1997.

Fidler. F E. A Theory of Leadership Effectiveness. New York: McGraw Hill Book Company. 1997.

Francis J. Yammarino. Alan J. Dubinsky. Lucette B. Corner dan marvin A. Jolson. "Women and transformasional and contigent reward Leadership : a multiple -levels- ofanalysis Perspective." academy of management Journal. 1997.

Gannon, Martin J. Management an Integrated Framework. edisi ke-2. Canada: McGraw-Hill International Book Company. 1982.

Gannon, Martin J.. 1982. Management an Integrated Framework. edisi ke-2. Canada. McGraw-Hil International Book Company.

Gibtiah. Fiqh Kontemporer. Palembang: IAIN Raden Fatah Press. 2006.

Grisham, Thomas. Cross-cultural Leadership. a Thesis for the Degree of Doctor of Project Management. Melbourne: Royal Institute Technology University. 2006.

Hakim, Atang Abd. dan Jaih Mubarok. Metodologi Studi Islam. PT. Remaja Rosdakarya: Bandung. 2008.

Halim, Sumayyah 'Abdul. Silsilah Ummahatul Mukminin: Sosok Ibu Teladan Kaum Muslimin. Cet. 10. Bandung: Irsyad Baitus Salam. 2007.

Haruna, Dennis. Model Kepemimpinan Perempuan dalam Lembaga Pendidikan Islam Studi Kasus di MTs Negeri Yogyakarta I. Skripsi UIN Sunan Kalijaga. Yogyakarta:2009. tidak diterbitkan. 
Hendyat, Soetopo. dkk. 1984. Kepemimpinan dan Supervisi Pendidikan. Malang : Bina Aksara.

Hendyat, Soetopo. et al. Kepemimpinan dan Supervisi Pendidikan. Malang : Bina Aksara. 1984.

Humm, Maggie. Ensiklopedia Feminisme. Yogyakarta: Fajar Pustaka. 2002.

Ibnu Kasir. Lubabut Tafsir Min Ibni Katsir. t. jilid 6. Bogor: Pustaka Imam Syafi'i. 2004.

Ibnu Kasir. Tafsir al -Qur'an al -Azim. juz 19. Bandung: Sinar Baru Algensindo. 2004.

Ibnu Manzur al-Afriqi al-Misri. Lisan al- 'Arab. dalam Program al-Maktabah al-Syamilah.

Ihsan, Fuad. Dasar-dasar Kependidikan. Jakarta: PT. Rineka Cipta. 2011.

Imam Abi Abdillah Syamsuddin Muhammad bin Ahmad. Siyar A'lam al-Nubula'. Juz I. Libanon: Bayt AlAfkar AdDauliyyah. 2004.

Imam Ahmad Musthofa al-Maraghi. Tafsir al-Maraghi. Mesir: Syirkah a-Maktabah wa Mathba'ah musthofa al-babi al Halaby wa awladuhu bi Mishri. 1946 M.

Imam al-Bukhari. Shahih Bukhari. juz V. kitab al-Magazy 84. bab kitab Nabi SAW. kepada Kisra dan Qaishar. hadis 4425 .

Imam al-Jalil al-Hafidz Abu al-Fida Ismail bin 'Amr al Quraisyi al ashri ad-Dimasyqi bin Katsir. Tafsir al-Qur'an alAdzim. Kairo: al-Faruq al Haditsah lil Thaba'ah wa alNasyir. 1421 H/ 2000 M.

Irwan, Abdullah. Reproduksi Ketimpangan Gender. Partisipasi Perempuan dalam Kegiatan Ekonomi dalam Dilema 
Perempuan; Antara Kegiatan Domestik dan Rumah Tangga.Yogyakarta: Aditya Media.1996.

Isjoni. Manajemen Kepemimpinan dalam Pendidikan. Bandung: Sinar Baru Algensindo. 2007.

Istinaroh. Kepemimpinan Perempuan di Pesantren Studi Kasus di PP Al-Luqmaniyyah Umbulharjo Yogyakarta. Skripsi Uin Sunan Kalijaga. 2015. tidak diterbitkan.

Istiqomah. Kepemimpinan Perempuan di Pondok Pesantren Studi di Pondok Pesantren Hajroh Basyir Salafiyah Kajen Margoyoso Pati. Tesis Universitas Islam Negeri Walisongo Semarang. 2014. tidak diterbitkan.

Jabir al-Shâl. Qishshah al-Nisa'. Beirut: Dâr al-Jill. 1985.

Jalal al-Din ibn 'Abd 1-Rahman ibn Abi Bakr al-Sayuthiy dan Jalal al-Din Muhammad ibn Ahmad al-Mahalliy. Tafsir al-Qur'an al- 'Azhim. Beirut: Dar al-Fikr. 1401 H /1981 M.

Jalaluddin al-Suyuthiy. Syarah Sunan al-Nasa'i. Juz IV. Beirut: Dar al-Fikr. 1415 H./1995 M.

John, Bernardin. H. Human Resource Management. New Jersey: Pearson Prentince Hall. 2007.

Kamaruzzaman. Kepemimpinan Wanita dalam Perspektif Sejarah Kerajaan Darussalam Aceh. Surabaya: Fakultas Adab IAIN Sunan Ampel. 2000.

Kanter, Rosabeth Moss. Men and Women of the Corporation. T.tp: Harper Collins Publishers. 1977.

Kartono, Kartini. Psikologi Wanita. Mengenal Gadis Remaja dan Wanita Dewasa. Bandung: Mandar Maju. 1989.

Kristiyanti, Eutrovia Iin dan Muhyadi. "Kepemimpinan Kepala Sekolah Perempuan". Jurnal Akuntabilitas Manajemen Pendidikan: 2015. 
M.Djadijono. "SI-MPR 2001 : Pemerintahan Baru. Program Kerja dan Prospeknya". Analisa CSIS. Tahun XXX/2001. No.3.

M.Sudibjo. "Proses Menuju SI MPR dan Masalah Ketatanegaraan RI". Analisa CSIS . 2001. Tahun XXX/2001 No.2.

Muhammad, Abi Abdillah bin Ismail bin Ibrahim bin alMughirah bin Bardzbah al-Bukhary. Shahih al-Bukhary. Juz V. Beirut: Dar al-Kutub alIlmiah. 1412 H / 1992 M.

Muhammad, Abu Isa bin Isa bin Sawrah al-'I'urmuziy. Sunan alTutmudziy. Juz IV. Beirut: Dar al-Kutub al-Ilmiyah. t. th.

Mulyadi. Kepemimpinan Kepala Sekolah. Malang: UIN-Maliki Press. 2010.

Munawwir, Imam. Asas-asas Kepemimpinan dalam Islam. Surabaya: Usaha Nasional. t.th.

Muslihah, Eneng. Ilmu Pendidikan Islam. Jakarta: Dadit Media. 2010.

Musthafa Ath-Thahhan. Ummahat al-Mu'minin fi Madrasah anNubuwwah terj. Martiah. Yogyakarta: Pustaka Fahimah. 2008.

Muthahari, Murtadlo. Hak-hak Wanita dalam Islam. Jakarta: Lentera. 1995.

Nawawi, Hadari. Kepemimpinan Menurut Islam. Yogyakarta: Gadjah Mada University Press. 1993.

Noer, Noor Huda. Perempuan dalam Perspektif Filsafat alQur'an. Al-Risalah. Vol. 10 No. 2. 2010.

Noor, Noer Huda. Wawasan al-Qur'an tentang Perempuan. Cet 1. Makassar: Alauddin Press. 2011.

Nurjannah, Ismail. Perempuan dalam Pasungan. Yogyakarta: LKIS. 2003. 
Oedjoe, Mien Ratoe. "Keefektifan Kepemimpinan Perempuan sebagai Kepala Sekolah". Jurnal Siti Chusniyah dan Moh Yasir Alimi. "Nyai Dadah: The Elasticity of Gender Roles and Life History of Pesantren Woman Leader". Jurnal Komunitas: 2015.

Owens, Robert G. Organization Behaviour in Education. Boston: Allyn and Bacon. 1991.

Permadi, Dadi. Kepemimpinan Transformasional Kepala Sekolah dan Komite Sekolah. Bandung: PT. Sarana Panca Karya Nusa. 2007.

Pfiffner, Jhon D. \& Robert Presthus. 1967. Public Administration. New York: The Ronald Press.

Pidarta, Made. Manajemen Pendidikan Indonesia. Jakarta: Rineka Cipta. 2004.

Piffner, Jhon. Public Administration. New York: The Ronald Press. 1967.

Rahardjo, M. Dawam. Dunia Pesantren dalam Peta Pembaharuan dalam Pesantren dan Pembaharuan. cet. ke-5. Jakarta: LP3ES. 1995.

Rahman, Afzalur. Nabi Muhammad Sebagai Seorang Pemimpin Militer. Jakarta: Bumi Aksara. 1991.

Ramayulis. Ilmu Pendidikan Islam. Jakarta: Kalam Mulia. 2008.

Ramayulis. Metodologi Pendidikan Agama Islam. Jakarta: Kalam Mulia. 2010.

Shihab, M. Quraish. 1995. Membumikan Al-Qur'an: Fungsi dan Peran Wahyu dalam Kehidupan Masyarakat. Cet. IV; Bandung: Mizan.

Shihab, M. Quraish. Ensiklopedia al-Qur'an: Kajian Kosa Kata. Jakarta: Lentera Hati. 2007. 
Shihab, M. Quraish. Tafsir al- Mishbah: Kesan dan Keserasian al Qur'an. Jakarta: Lentera Hati. 2002.

Shihab, M. Quraish. Wawasan AlQur'an: Tafsir Maudhu'i atas Pelbagai Persoalan Umat. Cet. III: Bandung: Mizan. 1996.

Siagian, Sondang P. Filsafat Administrasi Edisi Revisi. Jakarta: Bumi Aksara. 1990.

Siagian, Sondang P. Manajemen Strategik. Jakarta: Bumi Aksara. 1994.

Siagian, Sondang P. Teori dan Praktek Kepemimpinan. Jakarta: Rineka Cipta. 2010.

Siradj, Said Aqiel. Presiden Wanita dalam Abu Zahrah Ed. Politik Demi Tuhan. Cet.I: Bandung: Pustaka Hidayah. 1999.

Soeroto, Siti Soemandari. Kartini. Sebuah Biografi. Jakarta : Gunung Agung. 1978.

Soetrisno, Eddy. 100 Pahlawan Nasional 1 dan Sejarah Perjuangan. Jakarta: Ladang Pustaka dan Inti Media. 2001.

Stogdill. R.M. Handbook of Leadership A Survey of Theory and Research. New York: The Free Press. 1974.

Subhan, Zaitunah. "Rekontruksi Pemahaman Gender dalam Islam: Agenda Sosio-Kultural dan Politik Peran Perempuan”. Jakarta: el-Kahfi. 2002.

Subhan, Zaitunah. Tafsir Kebencian: Studi Bias Gender dalam Perspektif al-Qur'an. Yogyakarta: LKis. 1999.

Subroto, Suryo. Manajemen Pendidikan di Sekolah. Edisi Revisi. Jakarta: PT Asdi Mahasatya. 2004.

Sudaryono. Leadership Teori dan Praktek Kepemimpinan. Jakarta: Lentera Ilmu Cendikia. 2014. 
Sugiyono. Metode Penelitian Pendidikan. Bandung: Alfabeta.2009.

Suhadirman, Budi. Studi Pengembangan Kepala Sekolah. Jakarta: Rineka Cipta. 2012.

Sulaiman bin al-Asy'ar bin Syaddad bin Amru al-Azadi Abu Dawud as-Sijistani. Sunan Abiy Dawud. Beirut: Dar alFikr. 1988.

Sumardjo. Komunikasi Organisasi. Dalam: Dasar-dasar Komunikasi. Bogor: Sains KPM Press. 2010.

Sumarmo. Megawati Soekarnoputri: Dari Ibu Rumah Tangga Sampai Istana Negara. Depok: PT. Rumpun Dian Nugraha. 2001.

Sunaryo, Agus. "Simbolisme dan Essensialisme Kepemimpinan Kajian Fikih Siyasah Tentang Sosok Pemimpin Ideal Menurut Islam" Akademika. Vol. 19. No. 01. Januari Juni 201.

Syuqqah, Abu. 'Abd al-Halim. Tahrir al-Mar'ah fi 'Ashr alRisalah. Alih bahasa oleh Chairul Halim dengan judul "Kebebasan Wanita". Jilid 1-6. Jakarta: Gema Insani Press. Cet. I. 1997.

Tannenbaum, R.. L.R. Weschler. dan Massarik. Leadership and Organization. New York: Mc Graw-Hill. 1961.

Terry, George R. Prinsip-prinsip Manajemen. Diterjemahkan oleh J. Smith D. F.M. Jakarta: Bumi Aksara. 2003.

Umar, Nasaruddin. Argumen Kesetaraan Jender Perspektif Al Qur'an. Jakarta: Paramadina. 1999.

Usman, Husaini. Manajemen; Teori. Praktik dan Riset Pendidikan. Jakarta: Bumi Aksara. 2008.

Usman, Husaini. Manajemen: Teori. Praktik. dan Riset Pendidikan. Jakarta: PT Bumi Aksara. 2009. 
Wadud, Amina. Quran Menurut Perempuan: Meluruskan Bias Gender dalam Tradisi Tafsir. terj. Abdullah Ali. Jakarta: Serambi Ilmu Semesta. 2001.

Wirawan. Kepemimpinan. Teori. Psikologi. Perilaku Organisasi. Aplikasi dan Penelitian. Jakarta: Raja Grafindo Persada. 2013.

Wiriadiharja. Moeftie. Dimensi Kepemimpinan dalam Manajemen. Jakarta: Balai Pustaka. 1987.

Wursanto. Dasar-dasar Ilmu Organisasi. Yogyakarta: Andi Offset. 2003.

Yanggo, Huzzaimah Tahido. Fiqh Perempuan Kontemporer. Jakarta: al Mawardi Prima. 2001.

Yukl, Gary. Leadership. New Jersey: Pearson. 2010.

Yulk, Gary A. Leadership in Organisations. diterjemahkan oleh Yusuf Udaya dengan judul "Kepemimpinan dalam Organisasi.". Prenhallindo: t.p. 1998.

Yulk, Gary. Leadership in Organization. London: Prentice Hall International. Inc. 1994.

Zaitunah Subhan. Kodrat Perempuan: Takdir atau Mitos Yogyakarta: Pustaka Pesantren. 2004.

Zuhaili, Wahbah. Al Fiqh al Islami wa Adillatuhu. Beirut: Dar al Fikr. 1989. 